\title{
ANALYSIS OF PROPHYLACTIC ANTIBIOTICS USAGE IN CAESAREAN SECTION DELIVERY
}

\author{
Binti Muzayyanah $^{1}$, Yulistiani ${ }^{2}$, Didik Hasmono ${ }^{2}$, Nuraida Wisudani $^{3}$ \\ ${ }^{1}$ Master Program of Clinical Pharmacy, ${ }^{2}$ Faculty of Pharmacy, Universitas Airlangga, Surabaya, Indonesia, \\ ${ }^{3}$ Antimicrobial Stewardship Program Committee, Dr. Iskak Hospital, Tulungagung, Indonesia
}

\section{ABSTRACT}

\begin{abstract}
Caesarean section is the delivery through a surgical incision in the abdomen and uterus with various risks, such as Surgical Site Infection (SSI) which either occurs rapidly (24-48 hours postoperatively) or delayed. To reduce the risk of various post-cesarean section infections, prophylactic antibiotics are given. The administration of prophylactic antibiotics with recommended regimens, such as in developed countries as in the United States and Europe, with first generation of cephalosporins has not been applied in Dr. Iskak Hospital, Tulungagung. This hospital still used other types of antibiotics, such as cefotaxime or ceftriaxone. In addition, for several reasons, prophylactic antibiotics were continued with other antibiotics to reduce the risk of delayed infection. This study was designed to analyze the effectiveness of prophylactic antibiotics as recommended in cesarean section. This was a prospective observational study with consecutive sampling type, examined 41 mothers with cesarean section at the Department of Obstretics and Gynecology, Dr. Iskak Hospital, Tulungagung, Indonesia. This study was conducted from May to July, 2017. The results of the study showed that the effectiveness of prophylactic antibiotic use was 98\% based on the clinical parameters and maternal laboratory outcome, which showed that SIRS was in normal category. Whereas, there was one mother (2\%) who had SSI on day 10 postoperatively.
\end{abstract}

Keywords: Prophylactic antibiotics; cesarean section; SIRS; SSI

\section{ABSTRAK}

Seksio sesarea adalah kelahiran bayi melalui sayatan bedah di perut dan rahim dengan berbagai risiko. Salah satu risiko adalah Infeksi Daerah Operasi (IDO) yang dapat terjadi dengan cepat (24-48 jam paska operasi) maupun tertunda. Untuk mengurangi risiko berbagai infeksi paska seksio sesarea, diberikan antibiotika profilaksis. Pemberian antibiotika profilaksis dengan regimen yang dianjurkan seperti pada negara maju di Amerika dan Eropa dengan sefalosporin generasi I belum diberikan di RSUD Dr. Iskak Tulungagung dan masih menggunakan antibiotika jenis lain seperti sefotaksim atau seftriakson. Selain itu, karena beberapa ala san, pemberian antibiotika profilaksis masih dilanjutkan dengan pemberian antibiotika lain untuk mengurangi risiko infeksi yang tertunda. Penelitian ini meneliti efektifitas antibiotika profilaksis sesuai rekomendasi pada seksio sesarea, merupakan penelitian observasional prospektif dengan tipe consecutive sampling, meneliti 41 ibu melahirkan dengan seksio sesarea di Departemen Obstetrik dan Ginekologi, RSUD Dr. Iskak, Tulungagung dilakukan pada bulan Mei-Juli 2017. Hasil penelitian penggunaan antibiotika profilaksis menunjukkan $98 \%$ efektif berdasar parameter klinis dan laboratoris ibu berupa tanda SIRS yang berada dalam kategori normal, sedangkan satu ibu (2\%) mengalami IDO pada hari ke-10 paska operasi.

Kata kunci: Antibiotika profilaksis; seksio sesarea; SIRS; IDO

Correspondence: Binti Muzayyanah, Jl. MT. Haryono 185 B Tulungagung, East Java, Indonesia. Phone: +6285234565115. E-mail: bmuzayyanah@ymail.com

pISSN:2355-8393 • eISSN: 2599-056x • doi: http://dx.doi.org/10.20473/fmi.v54i3.10004

• Fol Med Indones. 2018;54:161-167 • Received 28 Aug 2017 • Accepted 1 Feb 2018

- Open access under CC-BY-NC-SA license • Available at https://e-journal.unair.ac.id/FMI/

\section{INTRODUCTION}

Caesarean section is the delivery through surgical incision in the abdomen and uterus (Cunningham et al 2010, Berghella 2016). Similar to other surgery in general, caesarean section has some risks of infection complications, including SSI. SSI, as defined by the United States Centers for Disease Control and Prevent- ion (CDC), is implied as an infection associated with surgical procedures that occur in surgical incisions or surrounding areas (wounds or incisional organs/spaces) within 30 days of procedure or within 90 days if prosthetic material is implanted on surgery (Anderson \& Sexton 2017). SSI incidence rate reaches $38 \%$ in surgical patients. In the United States, SSIs are estimated to develop in 2 to $5 \%$ of the patients undergoing extra 
abdominal clean surgery every year ( 1 of 24 patients undergoing hospitalized postoperative SSI operations) and $20 \%$ with intra-abdominal surgery (Ullman \& Rotschafer 2016, Anderson \& Sexton 2017).

Prophylactic antibiotics are administered to minimize the incidence of infection in surgery. Women who undergo caesarean section have 5-20-fold risk of getting an infection if prophylactic antibiotics are not given when compared with normal delivery (Berghella 2016). The provision of prophylactic antibiotics in clean cesarean section cases is recommended with the level of evidence IA (Schalkwyk \& Eyk 2010). A review of the Cochrane's study on 86 studies (>13,000 mothers) found that prophylactic antibiotics administration to women undergoing caesarean section was able to reduce the incidence of fever, wound infection, endometritis and complications of serious maternal infections (Smaill \& Gyte 2010, Schalkwyk \& Eyk 2010 ).

In Tulungagung, antibiotic treatment in cesarean section is still often followed by additional antibiotics based on various considerations. For example, the quality of the environment of surgical site and the sanitary hygiene of mothers who underwent cesarean section is poor. Dr. Iskak Hospital, Tulungagung still uses ceftriaxone prophylactic antibiotic or injectable cefotaxime that are given up to 24 hours post operation and continued with oral antibiotics for 5 days. The provision of the regimen has been considered to suppress the number of postcesarean section infections, as evidenced by the minimal incidence of SSI. In the initial study, there were 2 cases of SSI from 328 cesarean section during January-April 2017 (0.6\%). Those two mothers experienced SSI after discharging from hospital.

First generation cephalosporin class antibiotics, such as cefazolin, should be used as prophylactic antibiotics than later generations because they have high killing power against infection-causing gram-positive bacteria in cesarean section and high ability of penetration into larger tissues. The dose used as prophylaxis is generally $2 \mathrm{~g}$ if the mother weighs $<120 \mathrm{~kg}$ and $3 \mathrm{~g}$ if the mother weighs $>120 \mathrm{~kg}$. If the mother is allergic to cefazolin, the selection of other prophylactic antibiotics is 2-3 g ampicillin-sulbactam iv, 600-900 mg clindamycin iv or $15 \mathrm{mg} / \mathrm{kg}$ vancomycin but not more than $2 \mathrm{~g}$ iv if followed by either $5 \mathrm{mg} / \mathrm{kg}$ gentamicin iv or $2 \mathrm{~g}$ aztreonam iv; $500 \mathrm{mg}$ metronidazole iv plus $5 \mathrm{mg} / \mathrm{kg}$ gentamicin iv (Cunningham et al 2010, Schalkwyk \& Eyk 2010, Clifford \& Daley 2012, Bratzler et al 2013, Berghella 2016, Ulman \& Rotschafer 2016). The provision of prophylactic antibiotics with recommended regimens has not been implemented in Dr. Iskak Hospital, Tulungagung. Whereas, the use of ceftriaxone and cefotaxime is not recommended as a prophylactic antibiotic for reasons of its sensitivity and antibiotic treatment in cesarean section has been considered excessive when compared with the recommendations, while the administration of an irrational antibiotic will increase the occurrence of antibiotic resistance. Therefore, the study on the use of prophylactic antibiotics as recommended in mothers with cesarean section at Dr. Iskak Hospital, Tulungagung was needed and an evaluation of the effectiveness of its use was required. The analysis of the effectiveness of antibiotics in cesarean section was done by monitoring clinical and laboratory conditions to identify the sign of SIRS and surgical wound conditions.

\section{MATERIALS AND METHODS}

This was a prospective observational study with consecutive sampling technique. The subjects were mothers with cesarean section delivery who met the inclusion criteria of receiving a prophylactic antibiotic according to the recommendation (cefazolin or ampicillin sulbactam) and not taking antibiotics at least one week before admission. The mothers should also meet the exclusion criterion: not suffering from diabetes mellitus or HIV/AIDS. Number of samples were 41 mothers. Measurements were done on clinical conditions (temperature, pulse and breathing), the white blood cells were counted and CRP levels were measured 3 times before antibiotic prophylaxis, 24 hours postoperative and during the visit on day 10 postoperatively. The study was conducted from May to July 2017.

\section{RESULTS}

Sample demographic data are presented in Table 1. It can be seen that the number of mothers with high risk of pregnancy was 39\%. Gestational age in cesarean section was 38-42 weeks (aterm) which comprised $78 \%$ of the mothers. Those with once or more cesarean section were $30 \%$ and those in emergency condition were $85 \%$. There was an asthma comorbidity of $10 \%$ and the most indication was the infants malpresentations as much as $30 \%$.

Mothers were given with prophylactic antibiotics cefazolin and ampicillin sulbactam based on guidelines recommendation (Cunningham et al 2010, APhA 2013, Gyte et al 2014, Berghella 2016, Ullman \& Rotschafer 2016) and continued with antibiotics varied with profiles as shown in Table 2. The results of clinical and laboratory sign measurements were categorized according to each criterion presented in Table 3. 
Table 1. Sample demographic data

\begin{tabular}{|c|c|c|c|}
\hline Sample Characteristics & Notes & Sample Size $(\mathrm{N}=41)$ & $\begin{array}{l}\text { Precentage }(\%) \\
(\mathrm{N}=41)\end{array}$ \\
\hline \multirow[t]{3}{*}{ Age $^{1}$} & $<20$ years old & 3 & 7 \\
\hline & 20 - 35 years old & 25 & 61 \\
\hline & $>35$ years old & 13 & 32 \\
\hline \multirow[t]{3}{*}{ Pregnancy age } & Preterm & 5 & 12 \\
\hline & Aterm & 32 & 78 \\
\hline & Postterm & 4 & 10 \\
\hline \multirow{2}{*}{$\begin{array}{l}\text { Emergency of } \\
\text { operation }\end{array}$} & Emergency & 35 & 85 \\
\hline & Elective & 6 & 15 \\
\hline \multirow[t]{2}{*}{ Number of Operation } & First & 29 & 71 \\
\hline & Second or more & 12 & 29 \\
\hline \multirow[t]{5}{*}{ Comorbidities } & Asthma & 4 & 10 \\
\hline & Hypertension & 2 & 5 \\
\hline & Myoma & 1 & 2 \\
\hline & ALO (acute lung oedema) & 1 & 2 \\
\hline & No comorbidities & 33 & 81 \\
\hline \multirow[t]{13}{*}{ Surgical indications $^{2}$} & $\begin{array}{l}\text { Malpresentation of babies : } \\
\text { breech/transvere/oblique }\end{array}$ & 12 & 30 \\
\hline & Remain of caesarean section & 5 & 12 \\
\hline & Oligohydramnios & 4 & 10 \\
\hline & Postdate & 4 & 10 \\
\hline & Severe pre eclampsia & 4 & 10 \\
\hline & Asthma & 3 & 8 \\
\hline & Fetal compromized & 3 & 8 \\
\hline & Ante partum bleeding & 1 & 2 \\
\hline & Drip fail & 1 & 2 \\
\hline & Gemelli & 1 & 2 \\
\hline & High myopi & 1 & 2 \\
\hline & Hypertension & 1 & 2 \\
\hline & Absolute narrow pelvis & 1 & 2 \\
\hline
\end{tabular}

Note: 1. Age groupings based on maternal risk group during pregnancy (WHO 2014, NIH 2017), 2. Indication of surgery may be more than one, written is the most urgent

Table 2. Antibiotic profiles used

\begin{tabular}{|c|c|c|c|c|c|c|}
\hline \multirow{2}{*}{$\begin{array}{c}\text { Antibiotic } \\
\text { Types }\end{array}$} & \multirow[b]{2}{*}{ Antibiotic Names } & \multicolumn{3}{|c|}{ Regimen } & \multirow{2}{*}{$\begin{array}{c}\text { Number } \\
\text { of Sample } \\
(\mathrm{N}=41)\end{array}$} & \multirow{2}{*}{$\begin{array}{l}\text { Percentage } \\
\%)(\mathrm{N}=41)\end{array}$} \\
\hline & & Doses & Route & $\begin{array}{c}\text { Age } \\
(\text { day/s })\end{array}$ & & \\
\hline \multirow[t]{3}{*}{ Prophylaxis } & Sefazolin & $2 \mathrm{~g}$ & iv & $1 \mathrm{x}$ & 21 & 51 \\
\hline & Ampisilin-Sulbaktam & $3 \mathrm{~g}$ & iv & $1 \mathrm{x}$ & 18 & 44 \\
\hline & Ampisilin-Sulbaktam & $1.5 \mathrm{~g}$ & iv & $1 \mathrm{x}$ & 2 & 5 \\
\hline \multirow[t]{8}{*}{ Continuance } & Cefazolin $\rightarrow$ Cefadroxil & $\begin{aligned} & 3 \times 1 \mathrm{~g} \\
\rightarrow & 2 \times 0.5 \mathrm{~g}\end{aligned}$ & $\underset{\text { iv }}{\rightarrow \text { po }}$ & $\begin{array}{l}2 \\
\rightarrow 5\end{array}$ & 3 & 8 \\
\hline & Cefazolin $\rightarrow$ Cefadroxil & $\begin{aligned} & 3 \times 1 \mathrm{~g} \\
\rightarrow & 2 \times 0.5 \mathrm{~g}\end{aligned}$ & $\underset{\text { iv }}{\rightarrow \text { po }}$ & $\begin{array}{c}1 \\
\rightarrow 5\end{array}$ & 1 & 2 \\
\hline & $\begin{array}{l}\text { Ampicillin-Sulbactam } \rightarrow \\
\quad \text { Cefadroxil }\end{array}$ & $\begin{aligned} & 3 \times 1.5 \\
\rightarrow & 2 \times 0.5 \mathrm{~g}\end{aligned}$ & $\begin{array}{l}\text { iv } \\
\rightarrow \text { po }\end{array}$ & $\begin{array}{c}2 \\
\rightarrow 5\end{array}$ & 1 & 2 \\
\hline & $\begin{array}{l}\text { Ampicillin-Sulbactam } \rightarrow \\
\quad \text { Cefadroxil }\end{array}$ & $\begin{array}{l}3 \times 1.5 \mathrm{~g} \\
\rightarrow 2 \times 0.5 \mathrm{~g}\end{array}$ & $\underset{\mathrm{iv}}{\rightarrow \text { po }}$ & $\stackrel{1}{\rightarrow 5}$ & 2 & 5 \\
\hline & Ceftriaxone $\rightarrow$ Cefadroxil & $\begin{aligned} & 2 \times 1 \mathrm{~g} \\
\rightarrow & 2 \times 0.5 \mathrm{~g}\end{aligned}$ & $\underset{\text { iv }}{\rightarrow \text { po }}$ & $\begin{array}{l}1 \\
\rightarrow 5\end{array}$ & 1 & 2 \\
\hline & Ampicilin $\rightarrow$ Cefadroxil & $\begin{aligned} & 3 \times 1 \mathrm{~g} \\
\rightarrow & 2 \times 0.5 \mathrm{~g}\end{aligned}$ & $\begin{array}{l}\text { iv } \\
\rightarrow \text { po }\end{array}$ & $\begin{array}{l}1 \\
\rightarrow 5\end{array}$ & 1 & 2 \\
\hline & Cefadroxil & $2 \times 0.5 \mathrm{~g}$ & po & 5 & 31 & 77 \\
\hline & Cefadroxil & $2 \times 0.5 \mathrm{~g}$ & po & $5+5^{*}$ & 1 & 2 \\
\hline
\end{tabular}

Note: *: Sefadroxil $5+5$ was administered for 5 days and then it was stopped for 4 days, plus administration for 5 more days for SSI-exposed mothers. $\rightarrow$ : regimen replacement 
Table 3. Results of clinical condition measurement and laboratory results

\begin{tabular}{|c|c|c|c|c|c|c|c|c|}
\hline \multirow{2}{*}{ Parameters } & \multirow{2}{*}{ Criteria } & \multirow{2}{*}{ Category } & \multicolumn{6}{|c|}{ Number of Samples $\mathrm{N}=41(\%)$} \\
\hline & & & \multicolumn{2}{|c|}{ Pre-Op (\%) } & \multicolumn{2}{|c|}{24 Post-Op (\%) } & \multicolumn{2}{|c|}{$\begin{array}{l}\text { 10-11 Days Post-Op } \\
(\%)\end{array}$} \\
\hline 1 & 2 & 3 & \multicolumn{2}{|c|}{4} & \multicolumn{2}{|c|}{5} & \multicolumn{2}{|c|}{6} \\
\hline \multirow{2}{*}{ Temperature } & $36-38^{\circ} \mathrm{C}$ & $\mathrm{N}$ & 41 & $(100)$ & 41 & $(100)$ & 41 & $(100)$ \\
\hline & $<36$ or $>38^{\circ} \mathrm{C}$ & $\mathrm{TN}$ & 0 & $(0)$ & 0 & $(0)$ & 0 & $(0)$ \\
\hline \multirow[t]{2}{*}{ Pulse (HR) } & $<90 \mathrm{x} / \mathrm{min}$ & $\mathrm{N}$ & 41 & $(100)$ & 41 & $(100)$ & 41 & $(100)$ \\
\hline & $>90 \mathrm{x} / \mathrm{min}$ & $\mathrm{TN}$ & 0 & $(0)$ & 0 & $(0)$ & 0 & $(0)$ \\
\hline \multirow{2}{*}{$\begin{array}{l}\text { Pernapasan } \\
\text { (RR) }\end{array}$} & $<20 \mathrm{x} / \mathrm{min}$ & $\mathrm{N}$ & 41 & $(100)$ & 41 & $(100)$ & 41 & $(100)$ \\
\hline & $>20 / \mathrm{min}$ & $\mathrm{TN}$ & 0 & $(0)$ & 0 & $(0)$ & 0 & $(0)$ \\
\hline \multirow[t]{2}{*}{ WBC } & $*$ & $\mathrm{~N}$ & 41 & $(100)$ & 41 & $(100)$ & 41 & $(100)$ \\
\hline & & $\mathrm{TN}$ & 0 & $(0)$ & 0 & $(0)$ & 0 & $(0)$ \\
\hline \multirow[t]{2}{*}{ CRP } & $<100 \mathrm{mg} / \mathrm{L} * *$ & $\mathrm{~N}$ & 40 & (98) & 24 & (59) & 41 & $(100)$ \\
\hline & $>100 \mathrm{mg} / \mathrm{L}$ & TN & 1 & (2) & 17 & (41) & 0 & $(0)$ \\
\hline \multirow[t]{2}{*}{ IDO } & negative & $\mathrm{N}$ & - & - & 41 & $(100)$ & 40 & (98) \\
\hline & positive & $\mathrm{TN}$ & - & - & 0 & $(0)$ & 1 & (2) \\
\hline
\end{tabular}

Table 4. Clinical and laboratory data before and after advanced antibiotic prophylaxis and antibiotics prevention

\begin{tabular}{lllcc}
\hline Parameters & Units & Examination Time & $\begin{array}{c}\text { Value Range of } \\
\text { Clinical Dat }\end{array}$ & $\begin{array}{c}\text { Mean } \pm \text { Standard } \\
\text { Deviation }\end{array}$ \\
\hline Temperature & ${ }^{\circ} \mathrm{C}$ & Pre-op & $36.5-37$ & $36.66 \pm 0.13$ \\
& & 24 hours post-op & $36.5-37.5$ & $36.79 \pm 0.24$ \\
& & Days 10-11 post-op & $36.6-37$ & $36.85 \pm 0.12$ \\
\hline Pulse (HR) & $\mathrm{x} / \mathrm{min}$ & Pre-op & $78-90$ & $84.39 \pm 3.79$ \\
& & 24 hours post-op & $78-90$ & $84.34 \pm 3.66$ \\
& & Days 10-11 post-op & $80-88$ & $84.15 \pm 2.38$ \\
\hline Respiratory (RR) & $\mathrm{x} / \mathrm{min}$ & Pre-op & $18-20$ & $19.17 \pm 1.16$ \\
& & 24 hours post-op & $18-20$ & $18.92 \pm 1.01$ \\
& & Days 10-11 post-op & $16-18$ & $17.71 \pm 0.72$ \\
\hline WBC & $\mathrm{x} 10^{3} / \mu \mathrm{L}$ & Pre-op & $5.02-15.63$ & $10.64 \pm 2.44$ \\
& & 24 hours post-op & $9.76-22.30$ & $15.78 \pm 3.15$ \\
& & Days 10-11 post-op & $5.15-20.55$ & $9.82 \pm 2.87$ \\
\hline $\mathrm{CRP}$ & $\mathrm{mg} / \mathrm{L}$ & Pre-op & $2-192$ & $22.58 \pm 37.22$ \\
& & 24 hours post-op & $0-384$ & $134.63 \pm 82.42$ \\
& & Days 10-11 post-op & $0-96$ & $32.29 \pm 24.19$ \\
\hline
\end{tabular}

Table 5. Condition of maternal wound surgery with cesarean section

\begin{tabular}{llcc}
\hline \multirow{2}{*}{ Examination Time } & \multicolumn{2}{c}{ Criteria } & \multicolumn{2}{c}{ Results } \\
\cline { 3 - 4 } & Good & 40 & Number of Samples N=41 (\%) \\
\hline Day 3 post-op & 2 point inflammation & $1^{\text {a }}$ & $(2)$ \\
& IDO $(+)$ & 0 & $(0)$ \\
Days 10-11 post-op & Good & 39 & $(96)$ \\
& 1 point inflammation & $1^{\mathrm{b}}$ & $(2)$ \\
& IDO $(+)$ & $1^{\mathrm{c}}$ & $(2)$ \\
\hline Note: a $=$ Inflammation occurs in mother no. 16; $\mathrm{b}=$ inflammation occurs in mother 35; c $=$ SSI occurs in mother no. 15
\end{tabular}


The obtained data were compared to determine the effectiveness of antibiotics. The effectiveness of prophylactic antibiotics was analyzed by comparing the results of pre-op measurements with 24 hours postoperatively and then the 24-hour postoperative data were compared with those of days 10-11 postoperatively. Comparison of clinical and laboratory data are listed in Table 4. Wound condition was monitored, and the results are presented in Table 5.

\section{DISCUSSION}

To reduce the risk of postoperative infectious complications, such as rapid SSI, mothers are given with prophylactic antibiotics. The prophylactic antibotics used in the study was based on existing recommendations, which was cefazolin with alternative use of ampicillin sulbactam (Cunningham et al 2010, Berghella 2016, Ullman \& Rotschafer 2016). Sefazolin is a class of first generation cephalosporin antibiotics, including broad-spectrum antibiotics with higher effectiveness against gram-positive bacteria (APhA 2013), which is the most common cause of SSI in 24-48 hours postoperatively. Its high lipophilicity makes it easily penetrates into tissues. Sefazolin (first generation cephalosporin) is able to suppress the growth of bacteria, such as: Staphylococcus spp., Streptococcus spp., Escherichia coli, and Klebsiella spp. Sefazolin has a post antibiotic effect (PAE), which is the ability of continuous suppression activity of bacterial growth after the antibiotics are stopped. A study found that cefazolin with $12.5 \mathrm{mg} / \mathrm{kg}$ dose in animals showing PAE effect for 4 hours, and it has known that the PAE effect is also longer in vivo. The difference between in vitro and in vivo is the subinhibition effect on the growth and regrowth of the bacteria (Nightingale et al 2007).

In this study, the regimen was different from the recommendation due to various factors, such as enviromental hygiene, operating room sterilization, and maternal sanitary hygiene. So, to reduce the risk of delayed SSI, the mothers were given with advanced antibiotics. The administration of cefadroxil was done by considering its sensitivity to bacteria and safety of the mother and the baby during breastfeeding. Cefadroxil (first generation cephalosporin) has a high bioavailability (80-95\%) so that oral administration will yield almost the same results as intra venous administration and the absorption of cefadroxyl is not affected by food (Levison \& Levison 2011). This study found several advanced antibiotic administration which was the intravenous antibiotic administration prior to per oral cefadroxil for five days. In mothers with SSI, 3 x $0.5 \mathrm{~g}$ cefadroxil po for five days was re-administered for five days after four days without the drug.
The effectiveness of antibiotic use in this study was tested by comparing 5 parameters, ie. clinical measurements (temperature, pulse and breathing), surgical wound conditions, and laboratory parameters examination (WBC and CRP values). The SIRS criteria for infection monitoring were hyperthermia $\left(>38.3^{\circ} \mathrm{C}\right)$ or hypothermia $\left(<36^{\circ} \mathrm{C}\right)$, tachycardia (heart rate $>90 \mathrm{x} /$ min), and tachypnea (respiratory rate $>20$ ) (Branan et al 2016). The WBC criteria in the study were not determined as the SIRS criteria in general, but based on the parameters during pregnancy and post-natal conditions. The abnormal values of $\mathrm{WBC}$ in the final trimester of pregnancy were $>16 \times 10^{9} / \mathrm{L}\left(16 \times 10^{3} / \mu \mathrm{L}\right)$ and $>25 \times 10^{3} /$ $\mu \mathrm{L}$ at $24 \mathrm{~h}$ postoperatively (Ramsay 2010). The cut off value of CRP was $100 \mathrm{mg} / \mathrm{L}$ (Chileshe 2014).

Analysis of the effectiveness of prophylactic antibiotics was done by comparing measurements of clinical and laboratory markers as well as by monitoring wound conditions. The results of measurement of clinical and laboratory conditions are temperature, pulse and respiration, both before surgery (pre op) and 24 hours post operation as shown in Table 3 columns 4 and 5 . The result of measurement of clinical condition showed that $100 \%$ were in normal category with normal parameters according to SIRS criteria. WBC examination with cut off $>16 \times 10^{3} / \mu \mathrm{L}$ at before the section showed $100 \%$ in normal category. WBC 24 hours post operation with cut off $>25 \times 10^{3}$ obtained that $100 \%$ results were in normal category. CRP data with cutoff $100 \mathrm{mg} / \mathrm{L}$ pre- and $24 \mathrm{~h}$ post-operatively revealed 24 mothers in normal condition after operation. However, the CRP increased up to abnormal values in 16 mothers, while one mother remained in abnormal category. Such condition describes reaction against inflammation due to layered incision during the cesarean section. CRP increase $24 \mathrm{~h}$ post-operative is regarded as normal. Infection is indicated if the increase is more than $100 \mathrm{mg} / \mathrm{dL}$ on day 3 post-operative or more (Chileshe 2014). Both clinical condition and WBC of the mothers was also in normal category.

Analysis of antibiotic use was then performed by comparing clinical and laboratory measurements as well as by monitoring wound conditions between 24 hours postoperatively with days 10-11 post-operative as presented in Table 3 columns 5 and 6 . The results of clinical condition measurements were still in the normal category with normality values according to SIRS criteria. There was no increase of maternal WBC count on days 10-11 post-operatively compared to that of 24 hours post-operatively. All WBC count decreased variably in each mother. The decrease followed an improvement in post-operative conditions and will continue to improve to the normal range gradually, which may be reached in 4th week post-operatively. All 
mothers in this study had normal CRP values on days 10-11 postoperatively. This condition resulted from gradual improvement of the inflammatory effect of the incision, following the pattern of natural decline after cesarean section. Two percent of the mothers experienced SSI, subjected to wound care and finally the SSI was declared cured on the 20th postoperative day.

The overall outcome of the study was that there was no rapid SSI that occurred in 24-48 hours postoperatively and there was also no change in maternal clinical condition. On the 10th day post-operative there was one mother with SSI who recovered on day 20. This condition proved that antibiotics did not change clinical and laboratory parameters that were altered in normal pattern that cesarean section occurred up 24 hours postoperatively and all values decreased on the 10th postoperative day. The occurrence of SSIs is due to many factors, such as maternal sanitation higyene and not just depending on antibiotics alone.

The monitoring of antibiotic administration showed that various errors have still been found. For example, the antibiotics were not appropriate at the time of administration, the dosage and duration of administration were improper due to the lack of coordination and information between health-related professions and lack of guidelines as the basis of therapy. It is recommended to take action to improve communication between health care team with antibiotics and guidelines and fixed procedures on rational antibiotic use. The existence of standard Clinical Practice Guidelines and Standard Operational Procedure (SOP) and regular evaluation of the SOP as needed can also be used as a means of evaluation in its application. Professional knowledge is also needed on a continuing basis.

\section{CONCLUSION}

The administration of prophylactic antibiotics as recommended by the American Society of Obstetricians and Gynecologists (ACOG) with cefazolin or ampicillin sulbactam did not alter clinical and laboratory parameters, but it succeeded in decreasing the incidence of SSI. In this study, antibiotics used was continued up to day 5 post-operative, and SSI was still found in SSI on day 10 post-operative.

\section{ACKNOWLEDGMENT}

The authors are grateful to the Director of Dr. Iskak Hospital, Tulungagung, Head and staff of the Department of Obstetrics and Gynecology and PPRA, Dr. Iskak Hospital, Tulungagung. We are also grateful to the Dean of the Faculty of Pharmacy, Universitas Airlangga, Head and staff of the Pharmacy Master Program Pharmacy Faculty of Pharmacy, Universitas Airlangga, Surabaya, Indonesia.

\section{REFERENCES}

Anderson DJ, Sexton DJ (2017). Antimicrobial prophylaxis for prevention of surgical site infection in adults. Available from www.uptodate.com. Accessed on February 10, 2017, 1-37

APhA (2013). Drug information handbook a comprehensive resource for all clinicians and healthcare prefessionals 22th editions. Ohio, Lexi-comp

Berghella V (2016). Cesarean delivery: Preoperative issues. Available at: www.uptodate.com. Accessed on February 10, 2017, 1-25

Bratzler DW, Dellinger EP, Olsen KM, et al (2013). Clinical practice guidelines for antimicrobial prophylaxis in surgery. American Journal of HealthSystem Pharmacy 70, 195-283

Chileshe E (2014). Determination of C-reactive protein levels in blood of post caesarean section mothers at the University Teaching Hospital, Lusaka. Dissertation University of Zambia, 1-35

Clifford V, Daley A (2012). Antibiotic prophylaxis in obstetric and gynaecological procedures: A review. Australian and New Zealand Journal of Obstetrics and Gynaecology 52, 412-419

Cunningham FG, Leveno KJ, Bloom SL, et al (2010). Williams Obstetrics, Twenty-Third Edition. The United States of America, The McGraw-Hill Companies, Inc, p 587-608

Levison ME, Levison JH (2009). Pharmacokinetics and pharmacodynamics of antibacterial agents. Infectious Disease Clinics of North America 791-815

Nightingale $\mathrm{CH}$, Ambrose PG, Drusano GL, et al (2007). Antimicrobial pharmacodynamics in theory and clinical practice, second edition. New York, Informa Healthcare, p 129-146

Schalkwyk JV, Eyk NV (2010). Antibiotic prophylaxis in obstetric procedures. SOGC Clinical Practice Guideline. Juornal of Obstetrics and Gynecology Canada, 878-884

Smaill FM, Gyte GML (2010). Antibiotic prophylaxis versus no prophylaxis for preventing infection after cesarean section. Cochrane Database of Systematic Reviews, 1-176

Ullman MA, Rotschafer JC (2016). Antimicrobial prophylaxis in surgery. In Chisholm-Burns MA. Schwinghammer TL, Wells BG, et al. Pharmacotherapy Principles \& Practice Fourth Edition. New York, McGraw-Hill Education, p 1247125 